\title{
What the Survey of American College Freshmen Tells Us about Their Interest in Politics and Political Science
}

\author{
Sheilah Mann, American Political Science Association
}

Since 1966, the annual Freshmen
Survey has recorded the attributes, activities, expected educational outcomes, and life objectives of the students entering some 1600 institutions. Since 1973, the survey has been coordinated and analyzed by scholars at UCLA's Higher Education Research Institute. ${ }^{1}$ Selected findings from each annual survey report are featured regularly in The Chronicle of Higher Education and highlights from the report's introductory essay are summarized in newspapers. The most recent report, The American Freshman: National Norms for Fall 1998, has findings about how important political information and influence is to these new undergraduates, particularly in comparison with their other objectives, and on what proportion of them intend to major in political science. Overall, 1998 freshmen consider politics less essential than other personal, financial, and social objectives, and there has been some erosion since 1995 in the percentage of freshmen intending to major in political science in some types of colleges and universities, although the aggregate percentage of intended majors has remained the same.

\section{Interest in Politics among 1998 American Freshmen}

Political interest among entering college students has long been in decline and reached a record low in 1998. Freshmen who said that "keeping up to date with political affairs" is a very important or essential life goal comprised only $26 \%$ of respondents (Sax et al. 1998, 4). Politics was also among the least of their concerns in high school. Only $14 \%$ of 1998 freshmen reported discussing politics in the past year, barely more than half as many who reported discussing religion (26\%). Table 1 shows which objectives 1998 freshmen consider essential or very important and groups responses according to the type of college or university respondents attend and by gender.

Receiving political information $(26 \%)$ and influencing the political structure $(16 \%)$ are important to far smaller percentages of all students than are being well-off financially (74\%), raising a family ( $73 \%$ ), becoming "an authority in my field" $(60 \%)$, and helping others in difficulty $(60 \%)$. Although $74 \%$ of 1998 freshmen did volunteer work in high school, only $22 \%$ reported considering community action essential. And, while nearly twice as many believe becoming a community leader $(30 \%)$ is essential than believe exercising influence on politics is essential, the percentage of freshmen who value this objective is still low. In general, the freshmen share a considerably lesser concern for public than for personal objectives.

The aggregate responses indicative of political disengagement among freshmen can be qualified by an examination of students in different institutional settings and by gender. Overall, students attending historically black colleges are the students most interested in keeping up to date with politics, influencing the political structure, participating in community action, and being community leaders. A majority of these students also consider helping others in difficulty, influencing social values, and promoting racial understanding essential or very important. At the same time, larger majorities of black college students want to be well-off financially, an authority in their field, and successful in their own business. It appears that larger proportions of black college students are personally ambitious, socially responsible, and politically conscious.

In all institutions, slightly more freshmen men than freshmen women consider influencing the political structure essential or very important and more women than men consider community action to be essential or very important.

Freshmen interest in keeping up to date with politics is now less than half of what it was in $1966(58 \%)$, when the annual survey was first administered. After that survey, freshmen interest in politics declined in each year except 1972, hitting 38\% in 1979. It remained in the range of $38 \%$ to $42 \%$ in the early 1980 s. During the 1990s, freshmen interest in keeping up with political affairs has dropped from $42 \%$ in 1990 to its present record low of $26 \%$ (Astin et al. 1997, 57; Sax et al. 1998, 4).

Freshmen choice of non-centrist political positions has also diminished. More freshmen identify as middle of the road than in previous years $(57 \%)$. The proportion of freshmen who consider themselves liberal or left is $23 \%$, the lowest in 14 years; the proportion of freshmen who indicate that they are conservative or far right is at an eleven-year low of 20\% (Sax et al. 1998, 4, 30, 48, 66).

\section{Intentions to Major in Political Science}

A recent review of trends in undergraduate enrollments and majors based on APSA's Annual Survey of Political Science Departments drew upon data on the intentions of 1995 freshmen to major in political science for comparison (Mann 1996). ${ }^{2}$ The percentage of 1998 freshmen intending to major in political science is the same, overall, as it was in 1995: $2 \%$. Since freshmen can select a probable major from all fields of study_-disciplinary, inter- 
TABLE 1

Essential or Very Important Objectives of 1998 Freshmen, By Type of School and Gender (\%)

\begin{tabular}{|c|c|c|c|c|c|c|c|c|c|c|c|c|c|c|c|}
\hline & \multicolumn{3}{|c|}{ All Institutions } & \multicolumn{3}{|c|}{$\begin{array}{l}\text { 2-Year } \\
\text { Colleges }\end{array}$} & \multicolumn{3}{|c|}{$\begin{array}{l}\text { 4-Year } \\
\text { Colleges }\end{array}$} & \multicolumn{3}{|c|}{$\begin{array}{c}\text { Black } \\
\text { Colleges }\end{array}$} & \multicolumn{3}{|c|}{ Universities } \\
\hline & All & M & $\mathrm{F}$ & All & M & $\mathrm{F}$ & All & M & $\mathrm{F}$ & All & M & $\mathrm{F}$ & All & M & $\mathrm{F}$ \\
\hline \multicolumn{16}{|l|}{ Political Influence, Information ${ }^{a}$} \\
\hline Keep up to date with politics & $26^{b}$ & 29 & 23 & 18 & 21 & 14 & 29 & 32 & 26 & 38 & 39 & 37 & 33 & 35 & 31 \\
\hline $\begin{array}{l}\text { Influence the political } \\
\text { structure }\end{array}$ & 16 & 19 & 14 & 13 & 15 & 11 & 17 & 21 & 15 & 28 & 29 & 27 & 17 & 20 & 16 \\
\hline \multicolumn{16}{|l|}{ Community Action, Leadership } \\
\hline $\begin{array}{l}\text { Participate in community } \\
\text { action }\end{array}$ & 22 & 18 & 25 & 16 & 15 & 18 & 25 & 20 & 29 & 43 & 38 & 46 & 24 & 18 & 30 \\
\hline Be a community leader & 30 & 30 & 30 & 21 & 22 & 21 & 34 & 35 & 34 & 49 & 48 & 49 & 34 & 34 & 35 \\
\hline \multicolumn{16}{|l|}{ Professional, Financial } \\
\hline $\begin{array}{l}\text { Become an authority in my } \\
\text { field }\end{array}$ & 60 & 62 & 59 & 55 & 56 & 53 & 62 & 65 & 61 & 75 & 73 & 77 & 64 & 65 & 63 \\
\hline Be well-off financially & 74 & 76 & 72 & 76 & 76 & 77 & 72 & 76 & 70 & 88 & 85 & 91 & 74 & 77 & 71 \\
\hline $\begin{array}{l}\text { Be successful in my own } \\
\text { business }\end{array}$ & 34 & 45 & 33 & 40 & 47 & 33 & 38 & 45 & 33 & 63 & 66 & 60 & 38 & 44 & 34 \\
\hline \multicolumn{16}{|l|}{ Family, Social Assistance } \\
\hline Raise a family & 73 & 71 & 75 & 70 & 65 & 75 & 75 & 75 & 74 & 70 & 74 & 68 & 74 & 74 & 74 \\
\hline Help others in difficulty & 60 & 50 & 68 & 53 & 42 & 63 & 65 & 55 & 72 & 73 & 65 & 79 & 61 & 52 & 70 \\
\hline Promote racial understanding & 30 & 26 & 32 & 24 & 22 & 26 & 32 & 30 & 35 & 57 & 55 & 56 & 31 & 27 & 35 \\
\hline Influence social values & 36 & 32 & 40 & 33 & 28 & 37 & 40 & 36 & 43 & 50 & 45 & 53 & 36 & 31 & 40 \\
\hline
\end{tabular}

Source: Sax et al. $(1998,29,47,65)$.

a. Variables have been selected to contrast the differences between individual and collective objectives.

b. Percentages are rounded to the nearest whole number.

disciplinary, applied, and technicalthere are modest, even minuscule percentages of students selecting any one subject. In $1998,8.4 \%$ of the freshmen surveyed intended to major in a social science discipline or applied field. Political science accounts for nearly one-quarter $(24 \%)$ of these intended majors, second to psychology, the probable major of nearly one-half $(48 \%)$ of the 1998 freshmen picking a social sciences major.

In comparison with 1995 freshmen, there have been decreases in interest in the political science major among 1998 freshmen in some institutions and shifts in the appeal of the major between men and women. Table 2 displays data on 1998 freshmen intending to major in political science, cognate social sciences, and humanities disciplines according to the type of college and university they attend and by gender. Private schools and black colleges continue to record a higher proportion of political science majors than do public institutions. For the first time, there are more women $(2.1 \%)$ than men
$(1.8 \%)$ intending to major in political science. A possible explanation for this development is that even though interest in attending law school is at a record low among 1998 freshmen (Sax et al. 1998, 4), increasing percentages of law students are women. Nonetheless, political science continues to be "gender balanced" in comparison with psychology and sociology, which attract more women than men, and economics, history, and philosophy, which attract more men than women. Insofar as there are more women than men receiving bachelors degrees in the 1990s, and forecasts of undergraduate enrollment project a $15 \%$ growth in female students but only a $1 \%$ growth in male students over the next ten years (National Center for Educational Statistics 1998), political science should welcome the interest of women if the discipline is to maintain its prominence in undergraduate education.

The changes in the percentages of likely political science majors, by gender, within different types of in- stitutions since 1995 are summarized below. Although many of these changes involve fractions of one percent, the numbers of undergraduate students are substantial nationally and can be consequential for a particular college or university.

Universities: There is some attrition in university students intending to major in political science. Among public university freshmen, the decrease is from $2.5 \%$ to $2.2 \%$; among private university freshmen, the decrease is from $6.4 \%$ to $6.0 \%$, due to a drop in freshmen men from $6.3 \%$ to $5.5 \%$ while the percentage of private university women intending to major in political science $(6.4 \%)$ did not change.

Public and Nonsectarian FourYear Colleges: There is no aggregate attrition in intended majors, but slightly more of the 1998 probable political science majors are women- $1.8 \%$ in 1998 and $1.7 \%$ in 1995 in public colleges; $3.8 \%$ in 1998 and $3.6 \%$ in 1995 in nonsectarian colleges.

Protestant and Catholic Four-Year Colleges: There are slight declines 


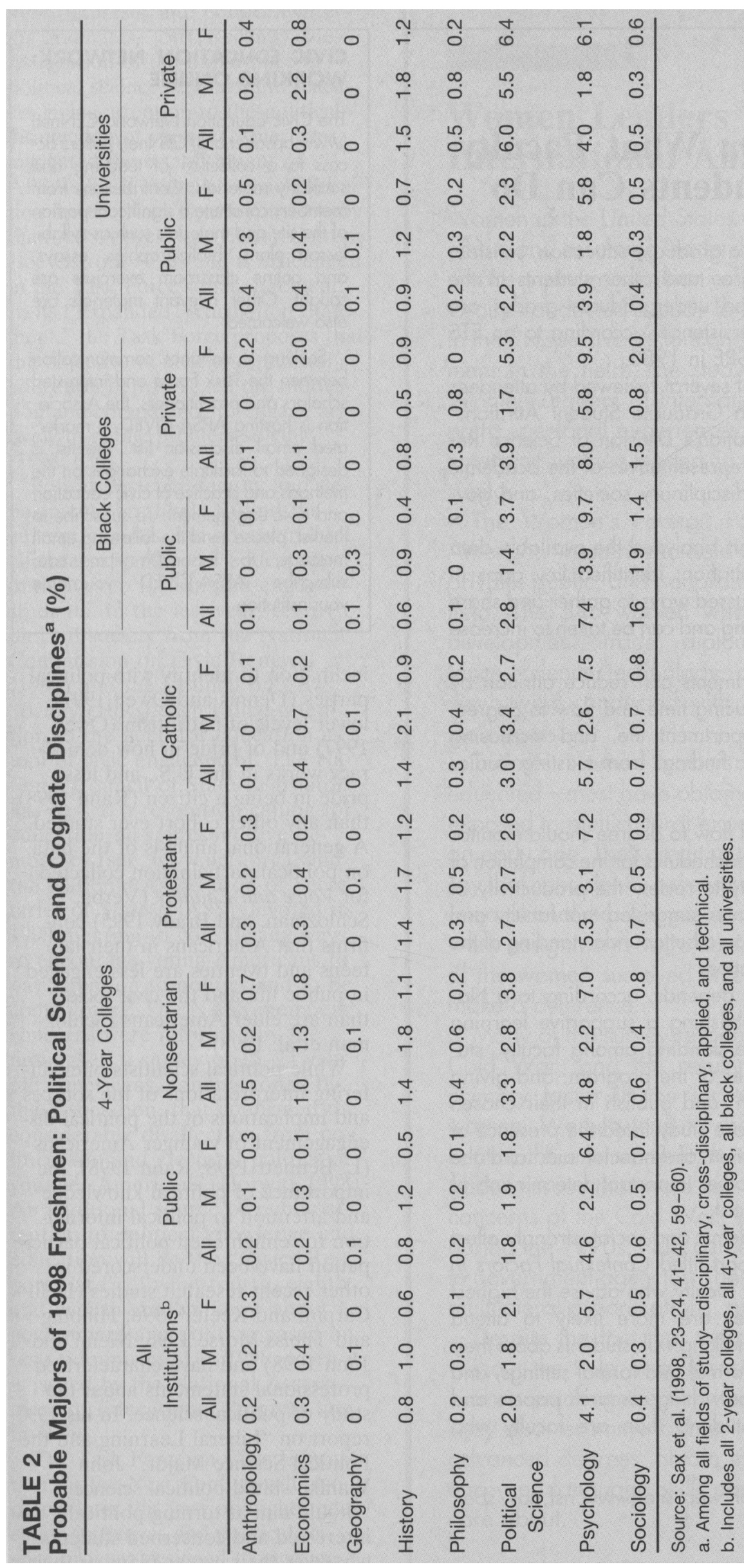

in intended majors in protestant colleges and in catholic colleges since $1995-2.7 \%$ in 1998 and $2.9 \%$ in 1995 in protestant colleges; $3.0 \%$ in 1998 and $3.1 \%$ in 1995 in catholic colleges. In protestant colleges, the drop is greater among freshmen men $(2.7 \%$ in 1998 and $3.1 \%$ in 1995 ) than among women $(2.6 \%$ in 1998 and $2.7 \%$ in 1995). In catholic colleges, the decline in intended majors is registered only among women, and this is the only type of college in which fewer of the freshmen women intend to major in political science-2.7\% in 1998 and $2.9 \%$ in 1995.

Black Colleges: The change in the gender composition of freshmen intending to major in political science was considerable among students in black colleges. The increase in intended majors in black public colleges since 1995 (2.8\% in 1998 and $2.4 \%$ in 1995), comes from a $1.2 \%$ increase in women majors $(3.7 \%$ from $2.5 \%)$ that is greater than the $0.8 \%$ decrease among freshmen men (1.4\% from $2.2 \%$ ). In contrast, private black colleges experienced a drop in freshmen selecting a political science major of $.7 \%$ (3.9\% in 1998 and $4.6 \%$ in 1995), attributable to a steep decline among freshmen men intending to major in the discipline that is only partially offset by an increase of $0.9 \%$ in women freshmen who are probable majors.

\section{Implications for Political Science}

The report of continuing, even increasing, disaffection from politics on the part of entering college students is consistent with recent political science research on the decline of civic engagement (Putnam 1995) and, particularly, young Americans' negative views of politics. Most of this literature makes a persuasive case that the change is generational, and common to the "Generation X" cohort rather than attributable to the life-cycle needs of young adults, in any generation, to focus on their personal and career goals. The current youngest American cohort displays greater political apathy and cynicism, lower attention to political information, lower voting turnout (S. Bennett 1997; S. Bennett and Rademacher 1997; Rahn 1998), less 


\section{Completing the Ph.D.: What Faculty, Departments, and Students Can Do}

A student's attitude about the benefits of a graduate education, satisfaction with their progress toward a degree and other students in the program, GRE scores, and self-reported undergraduate grades are strong predictors of graduate school persistence, according to an ETS survey of 2,500 persons who took the GRE in 1986.

The report on the ETS study was one of several reviewed by attendees of the September 1997 "Workshop on Graduate Student Attrition." Hosted by the National Science Foundation's Division of Science Resource Studies, the workshop attracted representatives of the academic and graduate education communities, disciplinary societies, and government scientific agencies.

During a day-long session, participants analyzed the available data on graduate student persistence and attrition, identified key gaps in knowledge concerning these issues, discussed ways to gather and share data, and conferred on steps that are being and can be taken to increase graduate study completion rates.

Current research suggests that departments can reduce attrition by modifying student selection criteria, reducing time and flow to degree, enhancing student participation in department life, and increasing incentives for faculty mentoring. Specific findings from existing studies indicate:

- Institutions seeking to reduce time and flow to degree should monitor student progress more regularly, establish schedules for the completion of degree requirements, and require faculty to review the productivity of $A B D s$ after a certain period. One presenter suggested that faculty and administrators should help students develop a better understanding of the structure and process of graduate education.

- Persistence by minorities and women depends, according to a National Research Council Study, on establishing a supportive learning environment; developing a shared understanding among faculty, students, and administrators of the purposes of the program; and giving students opportunities to work, research, and publish in their chosen fields. An Urban Institute-Wake Forest case study listed the presence of minority faculty, the amount and duration of financial aid, and the interest and involvement of a mentor as other important determinants of minority student success in graduate school.

- Faculty-student interactions, both academic and social, strongly affect persistence. Evidence presented in a report titled Contextual Factors in Graduate Student Attrition indicates that faculty who advise the highest numbers of successful Ph.D. candidates are more likely to attend colloquia, to spend more hours per week talking with students about their studies and work, to meet students in informal and formal settings, and to collaborate on academic tasks such as writing research papers and giving conference presentations with students than are faculty who advise few successful Ph.D. candidates.

The full summary is available on the NSF web site (www.nsf.gov/sbe) srs/nsf99314/start.htm).
CIVIC EDUCATION NETWORK: WORKING ONLINE

The Civic Education Network (CENnet) (unww.apsanet.org/CENnet/) offers access to a collection of teaching and scholarly materials. Contributions from members constitute a significant portion of the site and materials such as syllabi, lesson plans, bibliographies, essays, and online classroom exercises are sought. Other relevant materials are also welcomed.

Seeking to enhance communication between the Task Force and interested scholars and practitioners, the Association is hosting APSA-CIVED, a moderated email discussion list. The list is designed to facilitate exchanges on the methods and practice of civic education and civic engagement. To subscribe to the list, please send the following email message to listserv@h-net.msu.edu: subscribe APSA-CIVED yourname yourinstitution

inclination to identify with political parties (Dennis and Owen 1997), lower levels of patriotism (Owen 1997) and of pride in how democracy works in the U.S., and less pride in being a citizen (Rahn 1998) than any other cohort ever studied. A generational analysis of the data on political participation collected for Voice and Equality (Verba, Schlozman, and Brady 1995) confirms that Americans in their late teens and twenties are less engaged in public life and the civil society than are elder Americans (Schlozman et al. 1998).

While political scientists offer differing interpretations of the sources and implications of the political disengagement of younger Americans (L. Bennett 1998; Rahn 1998), the importance of political knowledge and attention to political information for enlightened political participation have been underscored in other recent research studies (Delli Carpini and Keeter 1996; Hibbing and Theiss-Morse 1996; Niemi and Junn 1998) and have characterized professional statements about the study of political science. In his 1991 report on "Liberal Learning and the Political Science Major," John Wahlke stated political science "should aim at turning politically interested and concerned students, whatever their career plans or their 
other interests, into politically literate graduates" (50). Recently, the recognition of the importance of political science scholars and teachers giving attention to the political disaffection of younger Americans instigated the establishment of APSA's Task Force on Civic Education for the Next Century in 1996 by then-APSA president Elinor Ostrom (see Ostrom 1996) and is articulated in the Task Force's first statement. In its "Expanded Articulation Statement," the Task Force proposes that the objective of civic and political education be to "Teach the motivation and competence to engage actively in public problem solving" (1998, 636).

Political science faculty and departments are likely to find the current campus and governmental climate supportive of education initiatives to inform and engage students. In the last year, reports on civil society from the National Commission on Civic Renewal (1998) and the Council on Civic Society (1998) each called attention to the need for education as a tool of civic engagement. The $\mathrm{Na}$ tional Council of State Legislators has passed a resolution calling for education on representative democracy (see, www.ncls.org), and the National Association of Secretaries of State (NASS) devoted its 1999 meeting to considering ways to encourage young Americans to pay attention to politics and to become voters. The NASS members' concerns were informed by the findings of a survey of 15-24 year old Americans, commissioned by the association, that confirmed the considerable disaffection from political life and electoral politics of younger Americans (Horwitt 1998). An additional source of public attention to political knowledge and education will be the "Civics $\mathrm{Re}$ port Card" of what fourth, eighth, and twelfth graders know about government and politics, based on tests administered in 1998, when it is issued by the National Assessment of Educational Progress late in 1999 .

The Task Force on Civic Education for the Next Century will also report later this year on higher education initiatives and political science projects designed to increase
Bulletin Board

\section{Women Leaders Emerge in International Affairs}

Women in the United States are entering the field of international affairs and assuming leadership positions within the field in record numbers. In recognition of this, the Women's Foreign Policy Group conducted a study to find out how women became leaders in their respective sectors and to answer questions about advance ment in the field. The study report, Leading by Example: U.S. Women Leaders in International Affairs, reveals that the career paths, personal experiences, and professional concerns of these emerging women leaders in the international community are very similar.

The Women's Foreign Policy Group sent surveys to 1,346 American women who hold mid-and senior-level positions in the private, public, and nonprofit sectors of the international relations field. The 546 women who replied work in human resources development, trade, diplomacy/defense, humanitarian assistance, science/technology, and communications. In-depth interviews were conducted with 43 women who were nominated by their peers.

Today's women leaders in international affairs are highly educated-most have obtained postgraduate degrees - and were exposed to multicultural experiences or traveled internationally at an early age. They credit much of their success to hard work, and say that consistently exceeding performance expectations, gaining international experience, and seeking out difficult or highly visible work assignments were keys to their career advancement. Many of the women surveyed entered the field with a strong desire to make a difference.

Many of the survey respondents also believe that the end of the Cold War, and the resulting redefinition of the field, was a primary factor in the increase of leadership opportunities for women. Women tend to specialize in areas such as education, health, the environment, human rights, humanitarian relief, and trade-issues that were seen as secondary to the foreign policy concerns of the Cold War, but which have come to the forefront during the 1990s. Plus, career opportunities are no longer limited to government agencies. These women are working for nonprofits, multilateral organizations, and multinational agencies.

Despite the fact that these women often rose to top positions without the help of a sponsor or mentor, most recommend that women entering the field today seek the guidance of a mentor. They also recommend that women wishing to enter the field earn advanced degrees, obtain internships, gain international experience and language skills early on, and focus on a specialty they care about. 
students' knowledge of politics and encourage students to connect their community service experiences to democratic practices. Comments and reports from faculty who have pro-

\section{Notes}

1. A summary of the data collected over the past three decades can be found on HERI's web site (www.gse.ucla.edu/heri/heri.html).

\section{References}

APSA Task Force on Civic Education for the Next Century. 1998. "Expanded Articulation Statement: A Call for Reactions and Contributions." PS: Political Science and Politics 31(September): 636-67.

Astin, A.W., S.A. Parrott, W.S. Korn, and L.J. Sax. 1997. The American Freshman Thirty Year Trends. Los Angeles: Higher Education Research Institute, University of California, Los Angeles.

Bennett, Lance W. 1998. "The UnCivic Culture: Communication, Identity, and the Rise of Life Style Politics." PS: Political Science and Politics 31(December): 741-61.

Bennett, Stephen Earl. 1997. "Why Young Americans Hate Politics and What We Should Do about It." PS: Political Science and Politics 30(March): 47-53.

$\longrightarrow$, and Eric W. Rademacher. "The 'Age of Indifference' Revisited: Patterns of Political Interest, Media Exposure, and Knowledge among Generation X." In After the Boom: The Politics of Generation X, ed. Stephen C. Craig and Stephen Earl Bennett. Lanham, MD: Rowman \& Littlefield.

Carter, Lief H., and Jean Bethke Elshtain. 1997. "Task Force on Civic Education Statement of Purpose." PS: Political Science and Politics 30(December): 745.

Council on Civic Society. 1998. A Call to Civil Society: Why Democracy Needs Moral Truths. Chicago and New York: University of Chicago Divinity School and the Institute for American Values.

Delli Carpini, Michael X., and Scott Keeter. 1996. What Americans Know about Politics and Why It Matters. New Haven: Yale University Press. grams or courses designed to meet these objectives can be sent to the civic education email discussion list (apsa-cived@h-net.msu.edu).To complement the work of the APSA
Task Force on Civic Education, the Association has developed a web site and email discussion list to increase dialogue and presentation of civic education materials.
2. Updated data on trends in political science enrollments and majors can be found in my "Political Science Undergraduate Enroll- ment and Majors: An Update" (www.apsanet. org/Professional/chairs).
Dennis, Jack, and Diana Owen. 1997. "The Partisanship Puzzle: Identification and Attitudes of Generation X." In After the Boom: The Politics of Generation X, ed. Stephen C. Craig and Stephen Earl Bennett. Lanham, MD: Rowman \& Littlefield.

Hibbing, John R., and Elizabeth TheissMorse. 1996. "Civics is Not Enough: Teaching Barbarics in K-12." PS: Political Science and Politics 29(March): 57-62.

Horwitt, Sanford D. 1999. New Millennium Project Part I: American Youth Attitudes on Politics, Citizenship, Govemment and Voting. Lexington, KY: National Association of Secretaries of State.

Mann, Sheilah. 1996. "Political Science Departments Report Declines in Enrollments and Majors in Recent Years." Political Science and Politics 29(September): $527-$ 33.

National Center for Education Statistics. 1998. Projections of Education Statistics to 2008. NCES 98-016. Washington, DC: Government Printing Office.

National Commission on Civic Renewal. 1998. A Nation of Spectators: How Civic Disengagement Weakens America and What We Can Do About It. College Park: University of Maryland.

Niemi, Richard G., and Jane Junn. 1998. Civic Education: What Makes Students Learn. New Haven: Yale University Press. Ostrom, Elinor. 1996. "Civic Education for the Next Century: A Task Force to Initiate Professional Activity." PS: Political Science and Politics 29(December): 75556.

Owen, Diana. 1997. "Mixed Signals: Genera- tion X's Attitudes toward the Political System." In After the Boom: The Politics of Generation X, ed. Stephen C. Craig and Stephen Earl Bennett. Lanham, MD: Rowman \& Littlefield.

Putnam, Robert D. 1995. "Tuning In, Tuning Out: The Strange Disappearance of Social Capital in America." PS: Political Science and Politics 28(December): $664-$ 83.

Rahn, Wendy. 1998. "Decline of American National Identity among Young Americans: Diffuse Emotion, Commitment and Social Trust, A Data Essay." Washington, DC: The Future of Democracy Workshop, The Annenberg Center, April 20.

Sax, Linda J., Alexander W. Astin, W.S. Korn, and K.M. Mahoney. 1998. The American College Freshman: National Norms for Fall 1998. Los Angeles: Higher Education Research Institute, University of California, Los Angeles.

Schlozman, Kay Lehman, Sidney Verba, Henry Brady, and Jennifer Erkulwater. 1998. "Why Can't They Be More Like We Were: Understanding the Generation Gap in Participation."

Verba, Sidney, Kay Lehman Schlozman, and Henry E. Brady. 1995. Voice and Equality: Civic Voluntarism in American Politics. Cambridge, MA: Harvard University Press.

Wahlke, John. 1991. "Liberal Learning and the Political Science Major: A Report to the Profession." PS: Political Science and Politics 24(March): 48-60. 